\title{
Sediment Accumulation Rate in Sayung Coast, Demak, Central Java Using Unsupported ${ }^{210} \mathrm{~Pb}$ Isotope
}

\author{
W.A. Gemilang ${ }^{1^{\star}}$, U.J. Wisha ${ }^{1}$, T. Solihuddin ${ }^{2}$, A. Arman ${ }^{3}$ and K. Ondara ${ }^{1}$ \\ ${ }^{I}$ Research Institute of Coastal Resources and Vulnerability, Ministry of Marine Affairs and Fisheries, \\ Jl. Raya Padang-Painan KM. 16, Bungus Teluk Kabung, Kota Padang, Sumatera Barat 25245, Indonesia \\ ${ }^{2}$ Marine Research Center, Ministry of Marine Affairs and Fisheries, \\ Komplek Bina Samudera, Jl. Pasir Putih II Lt 4, Ancol Timur, Jakarta Utara, DKI Jakarta 14430, Indonesia \\ ${ }^{3}$ Center for Isotopes and Radiation Application, National Nuclear Energy Agency, \\ Jl. Lebak Bulus Raya No. 49, Jakarta 12440, Indonesia
}

\section{ARTICLE INFO}

Article history:

Received 15 February 2019

Received in revised form 16 June 2019

Accepted 30 October 2019

Keywords:

Isotopes

Unsupported ${ }^{210} \mathrm{~Pb}$

Geochronology

Sediment accumulation rate

Sayung

Demak

\begin{abstract}
A B S T R A C T
Some efforts have been done to cope with coastal erosion and rob in Sayung Coast including mangrove plantation, hybrid engineering (HE), and hard structure protection. However, those efforts are not considered to be the best solution in reducing the impacts of the hazards. This study aimed to determine the sediment accumulation rates based on natural isotopes ${ }^{210} \mathrm{~Pb}$ dating and hydro-oceanographic modeling technique. According to ${ }^{210} \mathrm{~Pb}$ analysis, we calculated the sediment accumulation rates at Surodadi and Timbulsloko of $0.145 \mathrm{~cm} /$ year and $0.06 \mathrm{~cm} /$ year, respectively. The sediment compositions are dominated by terrestrial sediment typified by clay deposits. The sedimentary rate average of Sayung Coast prior to HE installation (2011-2013) was $0.195 \mathrm{~cm} /$ year. The rate of sediment accumulation rose to around $0.4 \mathrm{~cm} /$ year in 2016 in accordance with the increase of Mangrove area from around 409 hectares in 2013 to about 455.79 hectares in 2015. The increase of sedimentary rate recent years became an evidence that mitigation efforts to reduce abrasion temporarily succeeded.
\end{abstract}

\section{INTRODUCTION}

Demak District, Central Java is one of areas that experiences coastal erosion and shoreline changes problems [1]. The coastal erosion is mostly caused by the massive urban development and land conversion around the coast and surrounding areas which shift the hydrodynamic patterns resulting in the sediment imbalance in the coastal area [2]. Three sub-districts are undergoing coastal erosion such as Sayung, Bonang and Wedung. Among them, Sayung is the worst impacted land [3]. The total eroded area in Demak District has reached to 495.80 ha [4]. This erosion has damaged the coastal environments and mangrove ecosystems, including fish ponds and settlement areas [5].

Demak is geologically composed of young

*Corresponding author.

E-mail address: wisnu.gemilang@kkp.go.id

DOI: https://doi.org/10.17146/aij.2020.935 alluvial deposits which are still experiencing natural compaction until now. Recently, groundwater overpumping is believed to be the major factor causing land subsidence in Demak Coast in addition to other coastal hazards such as coastal erosion and sea inundation [6]. The mangrove degradation has also been one of the underlying causes of the coastal erosion up to several hundred meters landward in certain locations in the last few decades [7]. The worst impact caused by mangrove degradation is the tidal flooding or inundation (rob) to the settlement areas. A recent collaborative research project has concluded that the northern coast of Demak run into rapid coastal erosion and induced sea inundation up to 16 villages for the last 12 years [8].

The coastal erosion and mangrove degradation of Demak will continuously get worse if measures are not immediately taken. The massive establishment of fish ponds along the coast was 
believed to be the trigger for the mangrove destruction and conversion since the 1980s [9]. This land use change was followed by the construction of the breakwater around the ponds resulting in imbalanced sediment along the coast which in turn induced wide spread of sea inundation [9]. Sayung was the worst impacted district due to this sea inundation which was flooding villages e.g. Tambaksari in 1997 and Rejosari in 2004 [10]. Shoreline changes, caused by this coastal erosion, reached 771 ha area from 1999 to 2006, with an accretion area of 178 ha [11].

"Building with Nature" defined as an integrated coastal zone management approach that provides resilience by combining intelligent engineering, ecological rehabilitation, and sustainable land use, can be used as one of alternative solutions to cope with the problem in Demak. Hybrid Engineering (HE) is one of coastal protection structure types that inspired by nature, locally available, and environmentally friendly [12]. This permeable structure enables coastal restoration through natural processes such as sedimentation, so that the hydrodynamics and ecological conditions will return to the normal condition and stimulate the increase of land that was previously eroded [13]. This study aimed to determine the geochronology of the sedimentary rates in the Sayung Coast. Such information will support the determination of effective erosion mitigation as a structural mitigation effort.

\section{METHODOLOGY}

\section{Overview of study area and field survey}

The north coast of Java is geologically composed of young volcanic eruption, alluvial, and coastal deposits which are loose and uncompact materials. Quaternary sediments in this area consist of tuffaceous of clay stone, sand, silt, and clay [14]. The main constituent material of Sayung Coast in Demak is alluvial deposits (Qa) consisting of gravel, sand, clay, and silt. Demak is also bordered by the volcanic rock such as Qvtm (Tuf Muria) and Lava Muria (Qvlm) in the northeastern part, whilst, the eastern part is bordered by the Bulu Formation (Tmb) comprising interbedded limestone, sandy limestone, and clay limestone [15] (Fig. 1).

The geomorphic setting of the north coast of Java can be divided into three morphological units: lowland coast, corrugated hills, and elongated hills. The lowland coast unit covers a wide coastal plain area and is composed of alluvial deposits occupying almost all area in the north coast of Java. Corrugated hills units occur in the edge of the middle part of the north coast of Java and characterized by hills and valleys around the highlands [14]. The study area is positioned in the lowland coast unit, whereby it is broadly utilized as fish ponds and mangrove areas.

Demak region is tectonically controlled by strike-slip fault as seen in several lineaments on the Kudus and Magelang-Semarang regional geological map [15]. Moreover, the underground geological structure of Demak, that is prone to move on its geologically weak zone, causes subsidence and controls the tidal flood in the surface [16]. Furthermore, the existence of Muria-Kebumen and Pamanukan-Cilacap normal fault makes Central Java as a "unique geological formation". The two large strike-slip faults have sunken the northern area of Central Java contrasting the uplifted south area of Central Java [17]

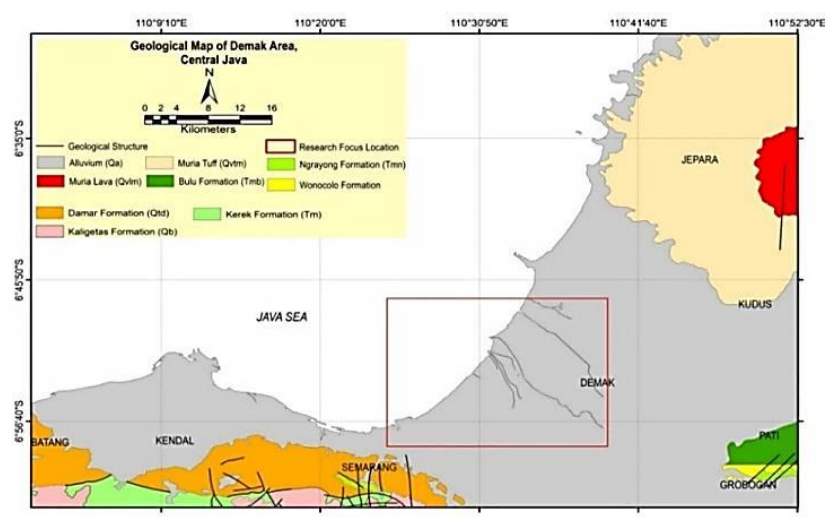

Fig. 1. Regional geological map of Central Java, part of Magelang and Semarang Quadrangle [18] and geological map of Kudus Quadrangle [15] and the study area (note: opened red square).

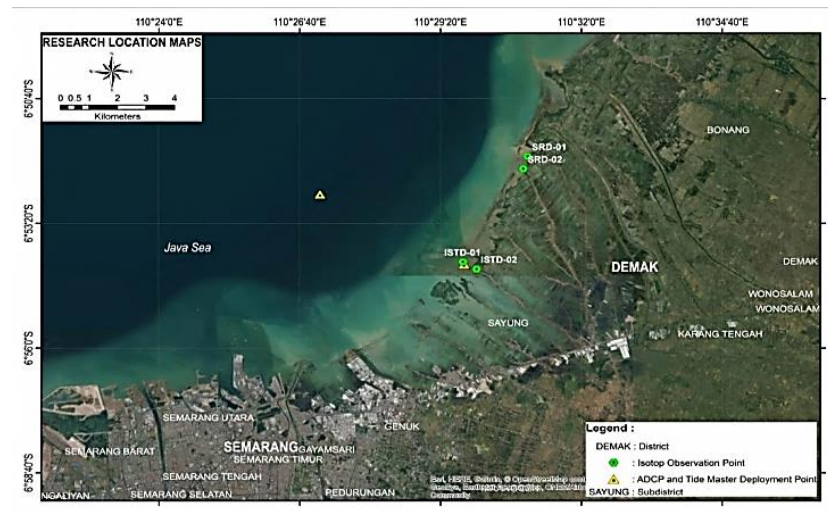

Fig. 2. Study area of Sayung Coast, Demak showing the sampling sediment sites including isotope observation points and the site of ADCP deployment.

Field survey was conducted at Sayung, Demak Central Java on 5-6 September 2016 and 12-13 April 2018. The sediment sampling sites were located near Moro Demak (ISTD-01) and in mangrove area (ISTD-02) (Fig. 2).

Sediment sampling for isotopes analysis was carried out at the back of the HE (SRD-02) and at 
the front of mangrove area (SRD-01) of Surodadi coast, Sayung (Fig. 2). These were selected to ensure a spatially representative record of sediment accumulation rates in Sayung coast. In addition, tidal and sea current data were recorded using the Acoustic Doppler Current Profiler (ADCP).

\section{Sediment sampling and isotopes ${ }^{210} \mathrm{~Pb}$ analysis}

Sediments were obtained by a 2-inch-diameter and 1-m-long PVC pipe. At each core, a $1 \mathrm{~cm}$ interval sediment from the top $10 \mathrm{~cm}$ and $5 \mathrm{~cm}$ interval sediment below the top $10 \mathrm{~cm}$ to the base section of the core was sub-sampled and stored in the sample container with labels. These samples were ${ }^{210} \mathrm{~Pb}$ analyzed in the Marine and Environment Laboratory, Center for Isotopes and Radiation Applications, National Nuclear Energy Agency of Indonesia (BATAN).

Sample preparation followed the procedures from Sabuti and Mohamed (2016) [19] with a slight modification from Lubis and Aliyanta (2010) [20]. The sediment samples were taken as much as $50 \mathrm{~mL}$ to do spontaneous deposition of ${ }^{210} \mathrm{~Pb}$ and ${ }^{209} \mathrm{Po}$ on $\mathrm{Cu}$ disk. Those two isotopes were then measured by using spectrophotometer alpha with PIPS (Passivated Implanted Planar Silicon) detector area of $450 \mathrm{~mm}^{2}, 20 \mathrm{keV}$ resolution and on the vacuumed condition. The supported ${ }^{210} \mathrm{~Pb}$ was determined from the value of ${ }^{210} \mathrm{~Pb}$ and unsupported ${ }^{210} \mathrm{~Pb}[21]$.

Sediment ages and accumulation rates were determined using CRS (Constant Rate of Supply) model. This model is practicable to count ages and accumulation rates of sediment [22-25]; employing a formula as follow:

$$
A=A(0) e^{-k t}
$$

The value of $A$ was gained from alleviating the total of unsupported ${ }^{210} \mathrm{~Pb}$ and unsupported ${ }^{210} \mathrm{~Pb}$ at the depth $x$, and $k$ is a radioactive decay constant of ${ }^{210} \mathrm{~Pb}=0.03114 /$ year, $A(0)$ is a sum of unsupported ${ }^{210} \mathrm{~Pb}$ at total cores $\left(\mathrm{Bq} / \mathrm{m}^{2}\right)$. Furthermore, $t$ is the sediment age (year) whereby it is gained employing formula;

$$
t=\frac{1}{k} \ln \frac{A(0)}{A}
$$

Sediment accumulation rate in each unit of time was counted from formula (3), $r$ is a sediment accumulation rate $\left(\mathrm{kg} / \mathrm{m}^{2} /\right.$ year $)$, and $C$ is an unsupported concentration of ${ }^{210} \mathrm{~Pb}$ at $x$ depth $(\mathrm{Bq} / \mathrm{kg})$.

$$
r=\frac{k A}{C}
$$

\section{ADCP measurement}

The ADCP was deployed at March $4^{\text {th }}, 2016$ 15:00 pm until March 22 $2^{\text {th }}, 2016$ 12:00 am (18 days) to measure physical parameters such as tides, temperatures, and currents. Sea current and tidal data were employed to validate the hydrodynamic model developed in this study [26]. The validation was performed by applying Root Mean Square Error (RMSE) formula [27] as follow:

$$
R M S E=\sqrt{\frac{1}{N} \sum(x i-y i)^{2}}
$$

where:

$$
\begin{aligned}
& N=\text { Total data } \\
& x i=\text { Model result } \\
& y i=\text { Field measurement data }
\end{aligned}
$$

\section{Flow model simulation}

Flow model was employed to determine the transport mechanism in the Sayung Coast which is triggered by water mass transfer caused by elevation changes. Tidal current patterns were simulated for 15 days, that will be displayed for four extreme tidal conditions.

To simulate hydrodynamic model, flow model flexible mesh $(\mathrm{fm})$ was developed to figure the tidal current pattern out in the form of two-dimensional model $[28,29]$. As an input model, bathymetry data retrieved from PUSHIDROSAL (Hydrography and Oceanography Center, Indonesian Navy) combined with field measurement and on-screen shoreline digitation from Google Earth 2016.

These data were used to generate a flexible mesh of study area (meshing stage). Moreover, the

\begin{tabular}{|c|c|}
\hline Parameter & Implemented in simulation \\
\hline \multirow[t]{4}{*}{ Simulation time } & Number of time step $=100$ \\
\hline & Time step interval $=30$ second \\
\hline & Start and stop simulation date $=$ \\
\hline & $7 / 03 / 201624.00-8 / 03 / 201600.50$ \\
\hline \multirow[t]{3}{*}{ Mesh boundary } & $\begin{array}{l}\text { Bathymetry } \\
\text { bathymetry map }\end{array}$ \\
\hline & $\begin{array}{l}\text { digitation combined with the field } \\
\text { measurement in } 2016\end{array}$ \\
\hline & $\begin{array}{l}\text { Coastline } \\
\text { digitation }\end{array}=$ Google Earth Image \\
\hline \multirow[t]{3}{*}{ Flood and Dry } & Drying depth $=0.005 \mathrm{~m}$ \\
\hline & Flooding depth $=0.05 \mathrm{~m}$ \\
\hline & Wetting depth $=0.1 \mathrm{~m}$ \\
\hline \multirow{3}{*}{$\begin{array}{l}\text { Boundary } \\
\text { condition }\end{array}$} & Tidal forecast for coordinates: \\
\hline & 1. Longitude: 110.4836 ; Latitude: -6.842 \\
\hline & 2. Longitude: 110.4399 ; Latitude: -6.895 \\
\hline
\end{tabular}
tidal forecast data were extracted from ERGtide software simulation in the form of time series data [30] which were used as boundary conditions of the developed model. The hydrodynamic model set-up is shown in Table 1.

Table 1. Set-up for hydrodynamic model. 


\section{RESULTS AND DISCUSSION}

\section{Hydro-oceanographic conditions}

Model validation is an essential stage to examine the error value in the model simulation. The gained RMSE of $11.21 \%$ for current data validation and $9.36 \%$ for surface elevation, respectively. These RMSE values are acceptable as the threshold is $<40 \%$ according to the boundary condition developed [31].

The surface current at the neap high tidal condition ranged from 0 to $0.149 \mathrm{~m} / \mathrm{s}$ with dominant southeasterly flow, while longshore currents were converged around Bedono coast forming a rip current and triggering sediment deposition in this area. During the spring high tidal condition, the surface current could reach up to $0.41 \mathrm{~m} / \mathrm{s}$ with prevailing southeasterly flow direction.

The highest longshore current speed was identified in the southern Sayung Coast proximal to Sriwulan ranging from a low of 0.11 to a high of $0.41 \mathrm{~m} / \mathrm{s}$. Furthermore, the tidal range was $0.6 \mathrm{~m}$ (Fig. 3). This pattern only represents the station ISTD-01 located in the water area. Unfortunately, the simulation could not be applied at station ISTD02 because of its landward location (near mangrove forest area). In fact, station ISTD-02 was not covered by water during ebb tides so that the simulation was impossible to be performed.

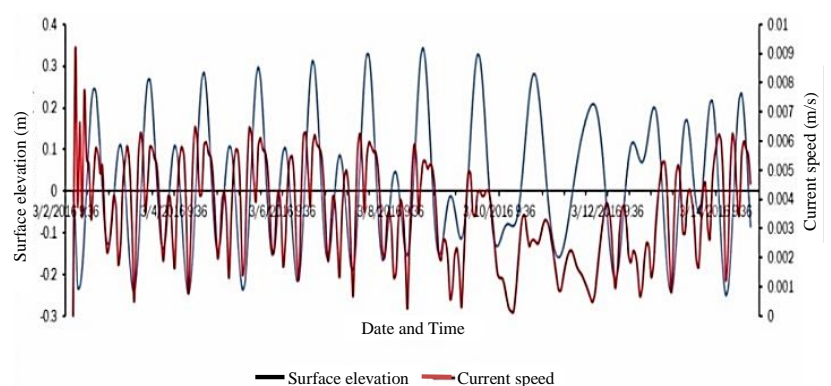

Fig. 3. Tides and currents pattern for 15 days simulation showing a fluctuation of surface elevation (blue line) and current speed (red line).

During the ebb tide, the surface water is lower than the land elevation, generating a weakened elevation pressure to the water, so that, the current flows predominantly seaward [32]. At the neap low tidal condition, the current speed ranged from $0-0.041 \mathrm{~m} / \mathrm{s}$, that was slightly weak transport mechanism during this condition. The most energetic water movement was observed near Sriwulan Village and Tanjung Emas Port area (Fig. 4). In contrast, at the spring low tidal condition, the current speeds ranged from $0-0.09 \mathrm{~m} / \mathrm{s}$ and the direction predominantly moved northwestward.
The pattern of tidal current flow has a big role in transporting materials sourced from terrestrial through the rivers entering the waters [32]. Moro Demak River is the biggest source of sediment budget draining off the waters through its canals. The higher the river discharge, the higher the volume of sediment entering the waters [33]. The sediment discharge from rivers will be further transported by the strong currents based on its predominant direction during the flood tide. On the other hand, the sediment will be relatively deposited during the ebb tide due to weaker speed of current [34].
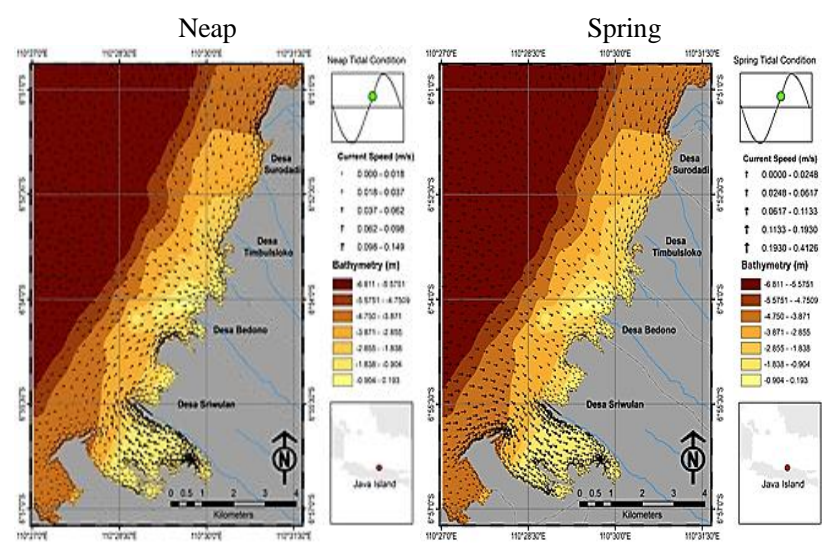

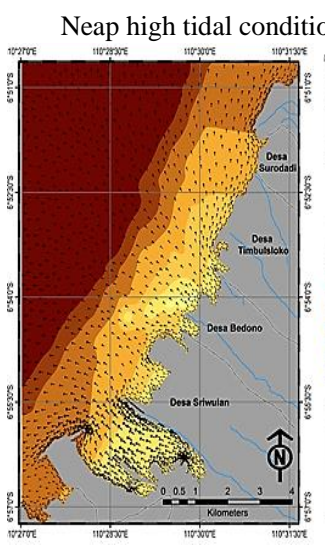

Neap low tidal condition
Spring high tidal condition
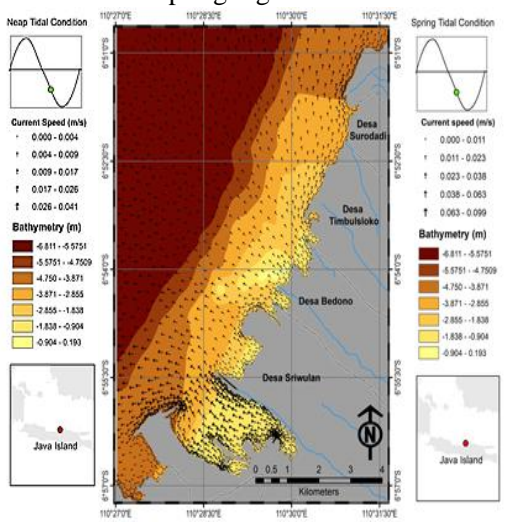

Spring low tidal condition
Fig. 4. Flow model simulation results depicting surface current patterns of Sayung Coast.

\section{The average of sedimentation rate}

The total supported ${ }^{210} \mathrm{~Pb}$ at ISTD-01 and ISTD-02 station are $39.33 \mathrm{~Bq} / \mathrm{kg}$ and $40.05 \mathrm{~Bq} / \mathrm{kg}$, respectively. These results are higher than other observation stations constituting 25.22 Bq.kg-1 and $31.07 \mathrm{~Bq} / \mathrm{kg}$ at SRD-01 and SRD-02, respectively (Fig. 5). Generally, the deeper the sediment layer, the lower the value of unsupported ${ }^{210} \mathrm{~Pb}$. Figure 5 also illustrates the $\log$-linier of unsupported ${ }^{210} \mathrm{~Pb}$ at certain depths that is not 
forming one straight line with a different slope [35]. Thus, we decided to divide four layers with different slopes for ISTD-01 sediment samples. The ISTD-01 sample analysis shows the presence of four sediment layers: LS1 (0-1 cm deep), LS2 (1-5 cm deep), LS3 (5-7 $\mathrm{cm}$ deep) and LS4 (7-10 $\mathrm{cm}$ deep). Whilst at ISTD-02, the sediment layers are LS1 (0-4 cm deep) and LS2 (4-6 cm deep) and layer (LS3) at a depth of $6-10 \mathrm{~cm}$.

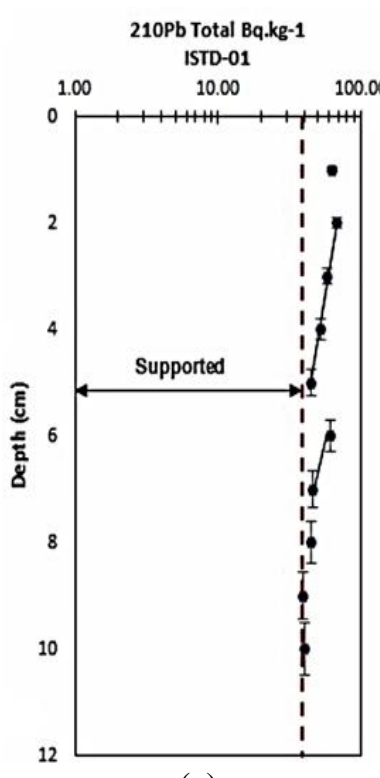

(a)

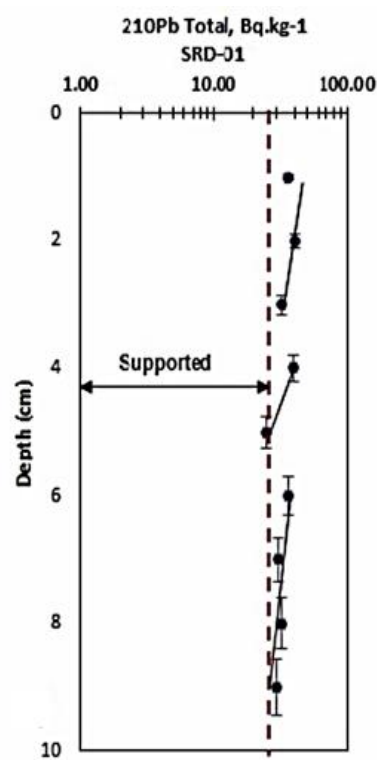

(c)

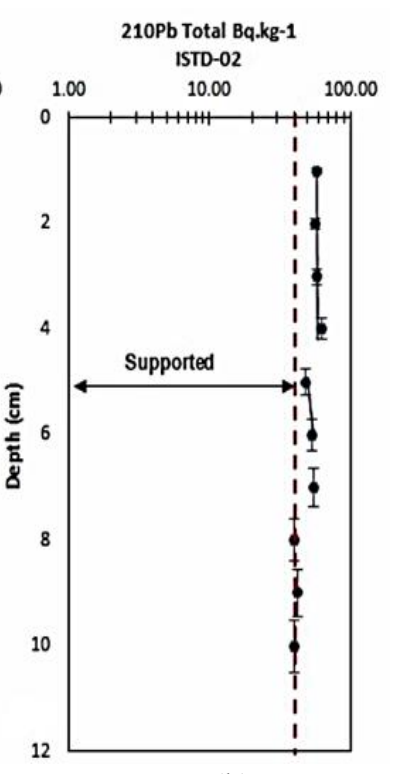

(b)

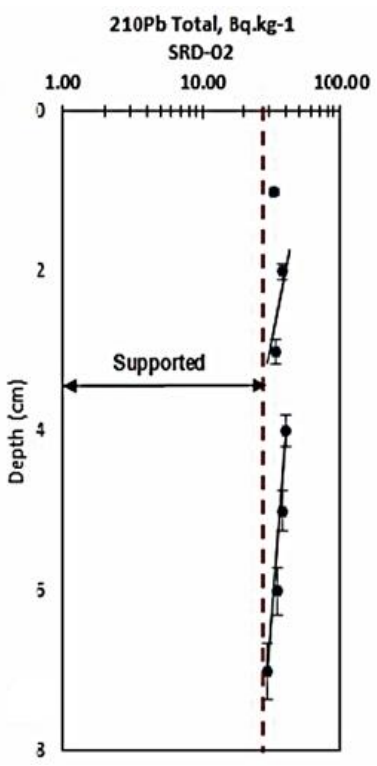

(d)
Fig. 5. The ${ }^{210} \mathrm{~Pb}$ profile toward the depth of the sample observation at Moro Demak/Timbulsloko In 2016 (a,b) and Surodadi Coast. Sayung in 2018 (c,d).

The log-linear graph slope of unsupported ${ }^{210} \mathrm{~Pb}$ at Surodadi Coast (SRD-01 and SRD-02) shows different layers of sediment in each sample.
The four layers at SRD-01 include LS1 $(0-1 \mathrm{~cm}$ deep), LS2 (1-3 cm deep), LS3 (3-5 cm deep), and LS4 (5-9 cm deep), while the three sediment layers at SRD-02 are LS1 (0-1 cm deep), LS2 (1-3 cm deep), and LS3 (3-7 cm deep). At ISTD-01 the depth layer of 7-10 cm while at ISTD-02 the depth layer of 6-10 $\mathrm{cm}$. In addition, the accumulation ages could not be detected because it exceeds the detection limit of isotope ${ }^{210} \mathrm{~Pb}$.

On the top layer of sediment: LS1 (ISTD-01), LS1 (ISTD-02) and LS1 (SRD-01) are higher than other layers. The highest sedimentation rate for SRD-01 station is on the third layer (LS3) with a rate of $0.24 \mathrm{~cm} / \mathrm{y}$ at a depth of $3-5 \mathrm{~cm}$. The ages of the sediment vary in each layer of the sediment core. At the bottom layer of ISTD-01 (6-7 cm deep) situated behind the mangrove area shows that the sediment deposition was in 1916 (100 years old), while on the uppermost layer of the core, the sediment deposition occurred in 2008 (10 years old). Positioned in front of mangrove area, the oldest sediment deposition for ISTD-02 occurred in 1957 (61 years old) at a depth of 5-6 cm, while the youngest (the uppermost layer) was in 2011 (7 years old).

At SRD-01 station, the oldest sediment deposition occurred in 1902 at a depth of 8-9 cm and the youngest (the uppermost layer) was in 2013. Whereas, at SRD-02 station, the oldest sediment deposition was in 1895 at a depth of 6-7 $\mathrm{cm}$ and the youngest (the uppermost layer) was recorded in 2016 (Fig. 6). The average of sedimentary rates in Timbulsloko (ISTD-01 and ISTD-02) was $0.15 \mathrm{~cm} /$ year and $0.14 \mathrm{~cm} /$ year, respectively. These conditions are caused by the existence of massive estuaries, resulting in massive sedimentation sourced from land.

Figure 6 also illustrates that sedimentation rates significantly occurred in 1975 at ISTD-01 station reaching $0.12 \mathrm{~cm} /$ year. While at ISTD-02, the rates were slightly lower reaching $0.09 \mathrm{~cm} /$ year in 2011. The rates were gradually declined in 1943 $(0.02 \mathrm{~cm} /$ year $)$ and in $1957(0.03 \mathrm{~cm} /$ year $)$ in those respective stations. During 1895-1992, the average of sedimentary rate at SRD-02 station was $0.04 \mathrm{~cm} /$ year. The increasing sedimentary rates were identified during 2006-2016 period becoming $0.28 \mathrm{~cm} /$ year. These conditions show that the mangrove restoration and coastal protection has begun during 2006-2016. At station SRD-01, the lowest sedimentary rate was identified during 1902-1977 period reaching $0.06 \mathrm{~cm} /$ year. However, the rates dramatically elevated in 1989 constituting $0.42 \mathrm{~cm} /$ year which then deteriorated during 1992-2013. 

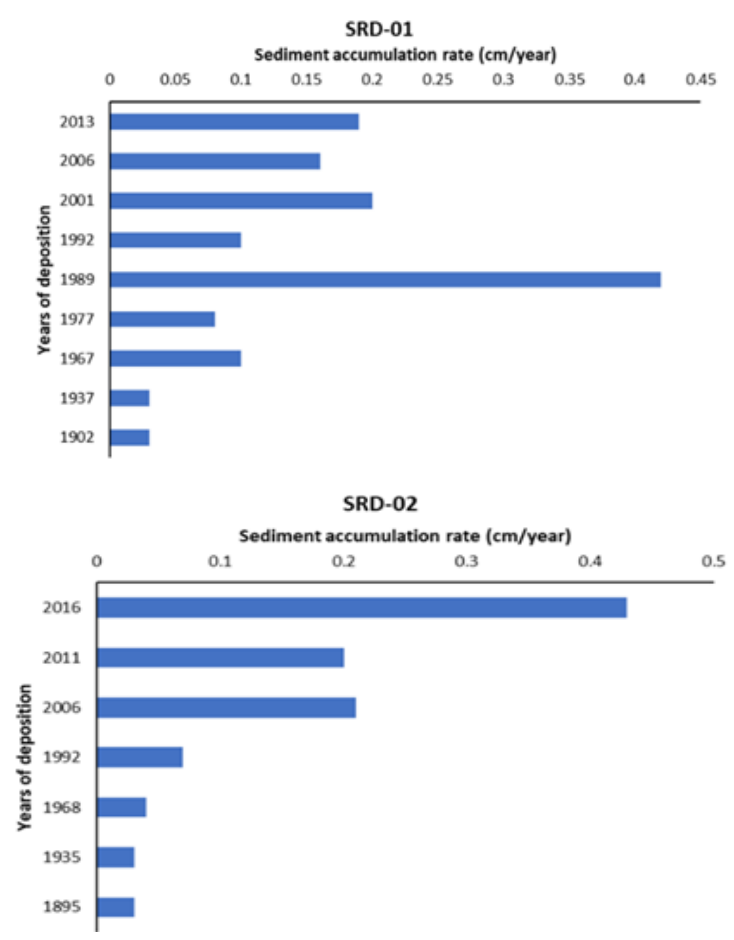

ISTD-01
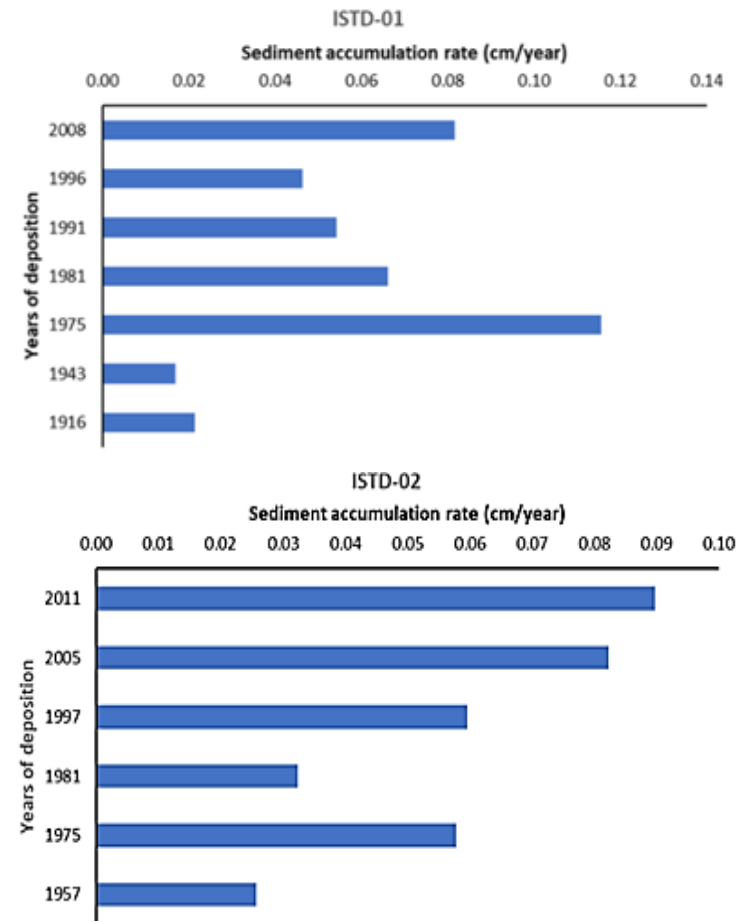

Fig. 6. The sedimentary rate of Sayung Coast according to natural radionuclide analysis ${ }^{210} \mathrm{~Pb}$.

\section{HE effectivity assessment according to sedimentary rates and mangrove area changes}

In regard to the results above, we observed that the sedimentation processes have started to increase since year 2000 in accordance with the changes of mangrove area during 2004 - 2013 (Fig. 7). The low sedimentary rate in Sayung Coast obviously occurred during 1974-2000 (Fig. 8).
The development of urban city threatened the existence of the mangrove area. Moreover, the land use changes were worsening the existing condition. This massive degradation raises the concern from the government and other stakeholders to rehabilitate the mangrove along Demak coastline. The measures had begun in 1997/1998 through the area development model of mangrove cultivation when rehabilitations were conducted [36].

The mangrove rehabilitation program had initiated in 2000 before the society continued the program [37]. It was proven that in 2000 the sedimentation rate increased at the same time with the improvement of mangrove area. However, the mangrove area deteriorated from 1974 until 1997 (Fig. 7). This condition was caused by the land conversion from mangrove areas to fish ponds [38]. The declination of mangrove areas correlates with the decreasing sedimentary rates at station ISTD-01 (from $0.12 \mathrm{~cm} /$ year to $0.05 \mathrm{~cm} /$ year).

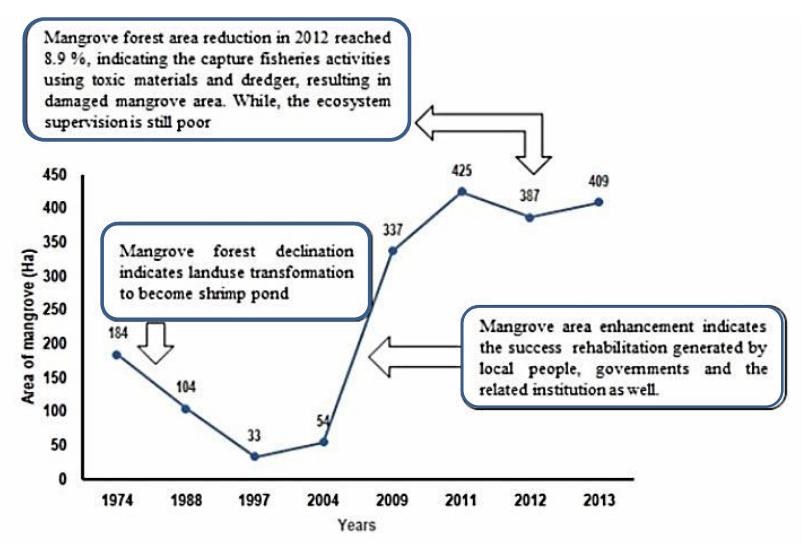

Fig. 7. The graph of mangroves area changes in the Sayung Coast (Source: Department of Marine Affairs and Fisheries Demak Regency, 2013 and Faturrohmah \& Marjuki, 2017 [39]).

The establishment of HE in 2013 added the coastal protection in addition to the mangrove rehabilitation [7]. The effort gives a good impact on the enhancement of sedimentary rate in Timbulsloko. Mangrove area increased significantly during 2013-2015 from 409 Ha to 455.79 Ha (Fig. 8) and was followed by the sedimentation enhancement from $0.2 \mathrm{~cm} /$ year to $0.43 \mathrm{~cm} /$ year. Unfortunately, the mangrove areas deteriorated from $425 \mathrm{Ha}$ to $387 \mathrm{Ha}$ in 2012 caused by the environmental degradation [38]. HE structures that are functioned as the wave breaker result in calmer water behind the gate-shaped of HE enabling the current to transport the sediment on the backside. Therefore, this structure functionates as a permeable dam which is expected to normalize the eroded coastline of 
Sayung. However, HE has several weaknesses. The structure will be damaged if there was a storm surf wave with the inundation more than 4 meters (overtopping) and the period of 8.83 seconds [12].

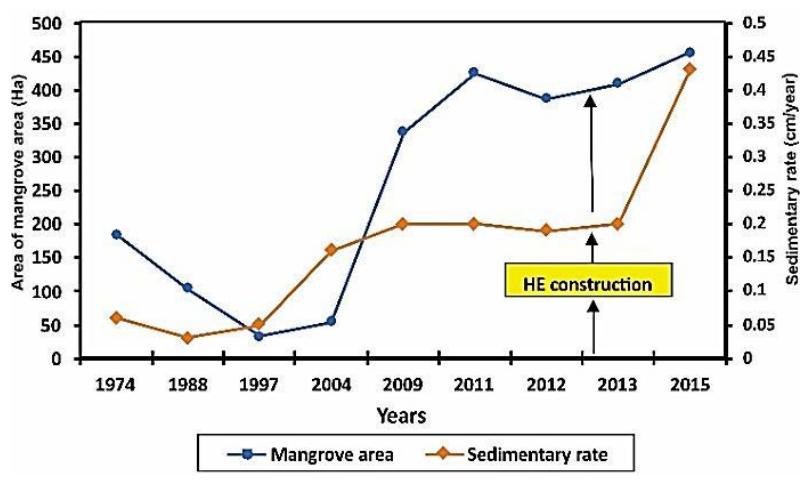

Fig. 8. The graph showing the correlation between the increasing of mangrove area and the sedimentary rate.

The unstable sedimentary rate is caused by the cohesive sediment which is easily scoured by the wave-driven currents [1]. According to the isotopes analysis, opposite values of sedimentary rates were identified in 2016 specifically at ISTD-01 station, the sediment accumulation rate relatively reduced, while at ISTD-02 station, the sedimentation rate enhanced. These conditions are mainly influenced by the variability of current patterns between those two locations. The ISTD-01 is located seaward where the current pattern has a dominant role in the transport mechanism. While, ISTD-02 is located landward (mangrove area) where the sediment discharge is predominant. According to [40], the sediment accumulation rate is also driven by the deformation of the current pattern due to the morphological shifting. The construction of either breakwater or the other coastal structures has a significant role in altering sediment behavior along the coast [1].

\section{CONCLUSION}

Based on ${ }^{210} \mathrm{~Pb}$ isotope analysis, the average of sedimentation rate is higher in Timbusloko compared to Surodadi coast. The increase of mangrove forest area in 2013 up to 2016 had a significant role in increasing sedimentation rate. The implementation of HE since 2013 had been succeeded to raise the mangrove cultivation areas, as a result, the sedimentation rate in the Sayung Coast increased instead.

The sediment accumulation rate in the Sayung Coast is mainly controlled by the variability of tidal current which was stronger during the high tidal conditions, resulting in higher turbulence and scour events. While, during the low tidal conditions, the weaker wave exposures cause the deposition of sediment from land and rivers provenance. The difference in the average of sedimentation rate between Surodadi and Timbulsloko is influenced by the presence of large existing estuaries. The increase of sedimentation rate in the area behind $\mathrm{HE}$ and several river mouths is one of the success evidences of mitigation efforts in reducing the coastal erosion in the Sayung Coast.

\section{ACKNOWLEDGMENT}

Authors acknowledge the Research Institute of Coastal Resources and Vulnerability (RICRV) for the research budget funding year 2016 supporting the research in Sayung, Demak Regency. Gratitude is also given to Department of marine Affairs and Fisheries of Demak and to everyone who is in charge in the Sayung research implementation.

\section{REFERENCES}

1. A. Ismanto, M. Zainuri, S. Hutabarat et al., IOP Conf. Ser. Earth Environ. Sci. (2017). 1

2. F.A. Sesli, F. Karsli, I. Colkesen et al., Environ. Monit. Assess. 153 (2009) 391.

3. M.A. Marfai, D.W. Tyas, I. Nugraha et al., J. Environ. Prot. (Irvine,. Calif). 7 (2016) 60.

4. K. Ervita and M.A. Marfai, Journal of Environmental Protection 08 (2017) 940.

5. S. Nandi, M. Ghosh, A. Kundu et al., J. Coast. Conserv. 20 (2016) 61.

6. B.D. Yuwono, M. Awaluddin, F.H. Kun et al., IOP Conf. Ser. Earth Environ. Sci. (2017) 1.

7. F.H. Tonneijck, H. Winterwerp, B. van Weesenbeeck et al., Building with Nature Indonesia: Securing Eroding Delta Coastlines, in: Design and Engineering Plan, Ecoshape (2015) 1.

8. S. Astuti, C. Muryani, and M.G. Rindarjono, IOP Conf. Ser. Earth Environ. Sci. (2018) 012087.

9. B.K. van Wesenbeeck, T. Balke, P. van Eijk et al., Ocean Coast. Manag. 116 (2015) 466.

10. M.P. Putri, Supriharyono and M.R. Muskananfola, Manag. Aquat. Resour. J. 3 (2014) 225.

11. A. Habib, S. Suripin and D.N. Sugianto, Int. 
Conf. Coast. Delta Areas (2017) 285. (in Indonesian)

12. H. Baskoro, W. Atmodjo and Purwanto, Journal of Oceanography 5 (2016) 340. (in Indonesian)

13. H. Prayogi, S. Widada and Hariadi, Journal of Oceanography 5 (2016) 137. (in Indonesian)

14. H. Moechtar, M.U. Lumbanbatu, Subiyanto et al., Geodinamika Kuarter Daerah Pantura Antara Cirebon Semarang, Pusat Survei Geologi Badan Geologi Kementerian Energi dan Sumber Daya Mineral, Bandung (2014) 33. (in Indonesian)

15. T. Suwarti and R. Wikarno, Geological Map of The Kudus Quadrangle, Jawa, Pusat Penelitian dan Pengembangan Geologi, Bandung (1992) 1. (in Indonesian)

16. H.Z. Abidin, H. Andreas, I. Gumilar, et al., Geomatics, Nat. Hazards Risk 4 (2013) 226.

17. A.H. Satyana and M.E.M. Purwaningsih, Lekukan Struktur Jawa Tengah : Suatu Segmentasi Sesar Mendatar, Indonesian Association of Geologists (IAGI), YogyakartaCentral Java Section (2002) 1. (in Indonesian)

18. R.E. Thaden, H. Sumadirdja and P.W. Richards, Peta Geologi Lembar Magelang dan Semarang, Jawa, Direktorat Geologi, Bandung (1975) 1. (in Indonesian)

19. A.A. Sabuti and C.A.R. Mohamed, Environ. Sci. Pollut. Res. 23 (2016) 18451.

20. A.A. Lubis and B. Aliyanta, Indonesian Journal of Chemisty 6 (2010) 256. (in Indonesian)

21. D. Cossa, R. Buscail, P. Puig et al., Chem. Geol. 380 (2014) 61.

22. G.J. Hancock and J.R. Hunter, Marine and Freshwater Research 50 (1999) 533.

23. J.A. Sanchez-Cabeza, P. Masque, I. AniRagolta et al., Prog. Oceanogr. 44 (1999) 313.

24. A.A. Lubis and B. Aliyanta, Indonesian Journal of Chemisty 6 (2006) 256. (in Indonesian)
25. T.F. Hamilton, S. Ballestra, M.S. Baxter et al., J. Environ. Radioact. 25 (1994) 113

26. U.J. Wisha, S. Husrin and G.S. Prasetyo, Indonesian Journal of Marine Sciences / Ilmu Kelautan 21 (2016) 123. (in Indonesian)

27. K.R. Jin and Z.G. Ji, J. Hydraul. Eng. 130 (2004) 1055.

28. I.R. Warren and H.K. Bach, Environ. Softw. 7 (1992) 229.

29. F.E. Mehdiabadi, M.M. Mehdizadeh and M. Rahbani, Indonesian Journal of Marine Sciences / Ilmu Kelautan 20 (2015) 1.

30. M. Mahmoudof, B. Banijamali and V. Chegini, J. Persian Gulf ((Marine Science) 3 (2012).

31. J. Chormański, D. Mirosław-Świạtek and R. Michałowski, Oceanol. Hydrobiol. Stud. 38 (2009) 65 .

32. U.J. Wisha, K. Ondara and G. Kusumah, Jurnal Segara 13 (2017). (in Indonesian)

33. A. Bayhaqi, M.R. Iskandar and D. Surinati, Oseanologi dan Limnologi di Indonesia 2 (2017) 83. (in Indonesian)

34. U.J. Wisha and A. Heriati, Omni-Akuatika 12 (2016) 1.

35. A.A. Lubis, B. Aliyanta and Y. Menry, Indonesian Journal of Chemisty 7 (2007) 309.

36. E. Setyowati, Partisipasi Masyarakat dalam Pengelolaan Hutan Mangrove di Desa Surodadi Kecamatan Sayung Kabupaten Demak, Institut Pertanian Bogor, Bogor (2010) 1. (in Indonesian)

37. A. Triyanti, M. Bavinck, J. Gupta et al., Ocean \& Coastal Management 150 (2017) 3.

38. M. Fikriyani and Mussadun, Jurnal Ruang 2 (2014) 81. (in Indonesian)

39. S. Faturrohmah and B. Marjuki, Majalah Geografi Indonesia 31 (2017) 56. (in Indonesian)

40. W.A. Gemilang, G. Kusumah, U.J. Wisha, et al., Jurnal Geologi Kelautan 15 (2017) 11. (in Indonesian) 